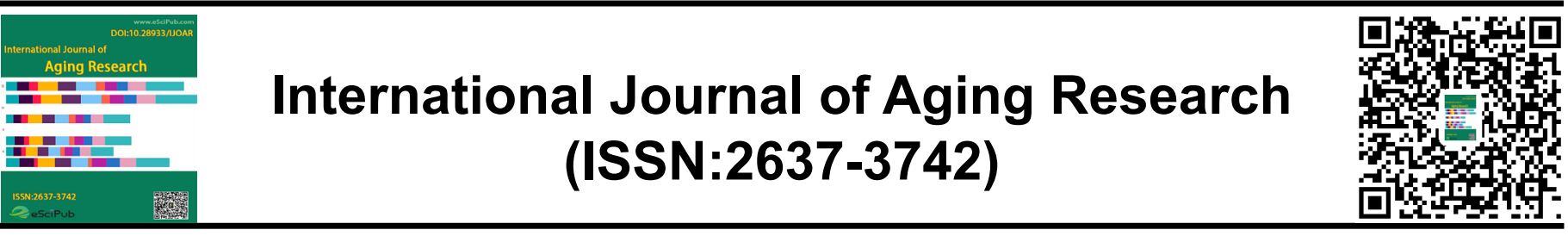

\title{
Sharing Stories as Legacy: What Matters to Older Adults ?
}

\author{
Neha Shivhare, Ph.D. ${ }^{1}$, Luciane Maria Fadel, Ph.D. ${ }^{2}$, David Kaufman, Ed.D. ${ }^{3}$ \\ ${ }^{1}$ Dayalbagh Educational Inst. (Deemed University), Agra, India. \\ ${ }^{2}$ Federal University of Santa Catarina, Brazil. \\ ${ }^{3}$ Simon Fraser University, Burnaby, Canada. \\ (Authors' contribution to the manuscript: All the authors contributed equally to the manuscript.)
}

\section{ABSTRACT}

Objectives: Legacy allows individuals to make meaning of their lives by passing on their experiences and beliefs to younger people and influencing their perspectives, perceptions, and actions. This mixed-methods study investigated: (1) What is important for older adults to share as legacy with families, friends and others, based on the types and features of their digital stories ? and (2) How do older adults' digital stories affect story viewers?

Methods: One hundred adults aged between 55 and 95 years participated in ten-week Elder's Digital Storytelling courses and created short digital stories. Using the content analysis approach, the story transcripts were thematically analyzed and iteratively coded by three researchers and the results were quantified. A diverse group of 60 viewers at a public event provided their reactions to the digital stories.

Results: The findings revealed that character, place, and family were chosen as the primary types by the older adults for their legacy digital stories. Accomplishment and career/school were the next most prominent story types. Moreover, these digital stories appeared to have a powerful impact on the viewers.

Discussion: A digital story is a powerful artifact to communicate an older person's legacy because it is based on familiar forms of communication, such as speech and photographs. The major legacy themes chosen by the older adults align with the findings of the research literature. The feedback from the viewers of the digital stories reflects these as a source of life wisdom and legacy for younger generations.

Keywords: Digital storytelling; Older adults; Elders; Legacy; Sto-

\section{Funding details:}

This work was supported by the AGE-WELL National Centre of Excellence (AW CRP 2015-WP4.3).

*Correspondence to Author:

Dr. David Kaufman

Faculty of Education, Simon Fraser University, Surrey, BC,, Canada.

How to cite this article:

Neha Shivhare, Luciane Maria Fadel, David Kaufman. Sharing Stories as Legacy: What Matters to Older Adults?. International Journal of Aging Research, 2020; 3:69.

\section{eScîPPub}

eSciPub LLC, Houston, TX USA. ry types 


\section{Introduction}

"I enjoy talking with very old people. They have gone before us on a road by which we, too, may have to travel, and I think we do well to learn from them what it is like." Socrates

Human beings are natural storytellers. Every time we recount a memory, we place it in time and space in the form of a story, with characters, actions, and consequences, in such a way that it becomes meaningful. It is through stories that people exchange meaningful information because stories provide a higher degree of meaning and emotion that can come from a mere set of facts. Stories create memorable and engaging experiences and thus provide a way to under- stand and make sense of who we are.

Considering that personal stories reveal something about the storytellers, it is expected that these stories can be instruments to share a legacy. In their research, Robinson and MurphyNugen (2018) ${ }^{1}$ analyzed the transcripts from interviews of seven older adults about their experience in a life review-writing group and found legacy as one of the strongest of their seven major emergent themes.

Hunter (2007-2008) defines legacy as a way of "leaving something behind after death and making meaning" of life's end (p. 313). Legacies in the form of life narratives and stories should not be understood as just a chronological sequence of life events, but as a continuous development of one's understanding and acquiring of personal beliefs based on his or her different experiences. These are created, transformed and transmitted through the personal, social and cultural interaction of one's self with family, friends, and society (Hunter,2008,p. $318)^{2}$.

Legacy allows individuals to make meaning of their lives by passing on their beliefs to younger people, thus acting as a link connecting different generations (Hunter, 2008, p. 318) ${ }^{2}$. Solie $(2004)^{3}$ considers legacy as a developmental need that must be addressed either consciously or unconsciously. According to Pevny (2016, p. $3)^{4}$, legacy can be as important as a calling or purpose in life, but these should not be equated because "the kind of person" an individual is, is more significant than the deeds that they perform.

The desire to leave behind a legacy emerges from an effort to overcome the fear of being completely lost after death. For humans, immortality has always held importance, and legacy is expected to provide some immortality. We live our lives driven by the motivation to make it purposeful to leave an imprint behind for people to remember us long after we are dead (Hunter \& Rowles, 2005, p. 328) ${ }^{5}$. Storytelling provides an opportunity for life reflection, life review, or reminiscence for older adults. According to Scott and Debrew (2009, p. 39) ${ }^{6}$, life reflection, life review, and reminiscence enable older adults to find meaning and purpose in the life they have lived.

Hunter (2008, p. 320) ${ }^{2}$ found "kindness of others, creativity, personal talents, stories of overcoming obstacles, stories of growth, and strong identification with certain roles" as the major themes of the life narratives of 38 women aged 31 to 90 years. Solie $(2004)^{3}$ considers the legacy themes chosen by older adults as vehicles to reflect what they would like to leave behind. Solie $(2004)^{3}$ identifies several themes such as: "acts of courage, decisions to forgive or repair a relationship, reflection on the quality of roles played in relationships and about the contributions made to the community, the impact of declining health, and family stories" (p. 170).

Robinson and Murphy-Nugen (2018) ${ }^{1}$ found that older adult perceived legacy as a gift from them to younger generations and wished that they could have had such a legacy from their own older generations. Older adults also assume legacy to be a means of getting recognition of 'selfworth' (Robinson \& Murphy-Nugen, 2018, p. 179) ${ }^{1}$. The emotional and social values associated with legacy are its most critical aspects because these are passed on to the present and future generations (Hunter, 2007-2008, p. 314)2. Though there is a belief that wisdom from older adults can benefit younger generations, there 
are not many platforms to bring together people from different age groups to share their experiences. Against this backdrop, digital storytelling provides a voice through which older adults may influence policies, perspectives and perceptions (Jenkins, 2015) ${ }^{7}$.

According to Pecorini and Duplàa $(2017)^{8}$, life reviews by older adults, whose understanding about life is deeper and different from that of youth, inspire resilience and mutual learning among the young people. Older adults' narratives are powerful tools for educating younger generations and can lead to a better quality of life for the narrator as well as for the listener or viewer.

Digital stories can promote awareness about issues related to seniors, such as "domestic violence, coping with illness, caregiver support, and hospice life stories" (Hewson, Danbrook, \& Sieppert, 2015, p. 139) ${ }^{9}$. It is no exaggeration to say that there is an enormous need for understanding the perspectives and feelings of older adults, and digital stories, along with other forms of older adults' narratives, are powerful tools for this. Viewing and analysing digital stories provide an insight into socio-emotional and psychological facets of older adults, and hence also have the potential to contribute to the reminiscence therapy.

\section{Research Question}

The research questions addressed in this study are: (1) When given an opportunity to create a legacy digital story, which types are chosen by the older adults? (2) What are viewers' reactions to the older adults' digital stories?

This study investigated what is important for older adults to share with their families, friends and others, based on the types and features of the stories they chose to create and leave as their legacy. Participants in the ten-week Elder's Digital Storytelling courses conducted in Western Canada created these short digital stories. To fulfil the objective of the present study, 100 stories were content-analyzed and iteratively coded by the three authors. This research is original in investigating the types and features of legacy stories developed by older adults.

\section{Methods}

This study is based on the qualitative analysis of 100 digital stories created by older adults who participated in the ten-week digital storytelling courses. The courses were offered as a part of the larger AGE-WELL project that aimed to use technology to enhance the lives of older adults (www.agewell-nce.ca).

\section{The Digital Storytelling Course}

The digital storytelling course is described in more detail elsewhere (Hausknecht, VanchuOrosco, \& Kaufman, 2017) $)^{10}$, so a shorter description is provided here. The course was developed based on the Digital Storytelling Cookbook (Lambert, 2010) ${ }^{11}$ and creative writing and film techniques. It was designed with two separates, yet integrated, phases: story creation and digital production. These two phases provided time for deciding on and writing a well-constructed story before incorporating digital technology (photographs, video, audio, and simple visual effects). Each participant was asked at the start to think of a story from their life that was important or meaningful to them. This story would serve as a legacy that they would provide to their family, friends, and others.

\section{Participants and Consent}

The 100 study participants were adults aged between 55 and 95 years who participated in the digital storytelling courses conducted by our team in Western Canada, between 2015 and 2018. All the participants were asked to sign a consent form to permit the researchers to use their demographic information and developed stories for research. Although, the participants were told that giving consent was not a requirement for participation in the course, nearly all of them signed the consent form.

\section{Data Collection}

Demographic data. Participants who had signed the consent form completed a short survey on their demographic background at the start of the course. 
Table 1a. Framework Used to Code the Digital Stories

\begin{tabular}{|c|c|}
\hline Digital story type & Sample Excerpts \\
\hline $\begin{array}{l}\text { Important person } \\
\text { Character } \\
\text { Military }\end{array}$ & $\begin{array}{l}\text { "Grandma met the baby's father, Nathan, at a dance in East London. He was a smooth- } \\
\text { talking American soldier. She was soft-spoken, shy, and very naive." (Character) }\end{array}$ \\
\hline $\begin{array}{l}\text { About an event or a } \\
\text { place } \\
\text { Place } \\
\text { Event } \\
\text { Adventure } \\
\text { Accomplishment } \\
\text { Family life } \\
\text { Immigration } \\
\text { Historical } \\
\text { Travel }\end{array}$ & $\begin{array}{l}\text { "Lyons Falls was a paper-mill town, and as a little kid, I thought I knew as much as anyone } \\
\text { about making paper. My dad was the chief engineer at the mill, and I always went along } \\
\text { when he toured family visitors around." (Place) } \\
\text { "Uncle Einar told me that housing was plenty in Vancouver and he would help me to get } \\
\text { settled. With my mother's blessing, I left my country and landed in Vancouver." } \\
\text { (Immigration) }\end{array}$ \\
\hline $\begin{array}{l}\text { About what someone } \\
\text { does } \\
\text { Career } \\
\text { School }\end{array}$ & $\begin{array}{l}\text { "I attended a one-room schoolhouse through } 6^{\text {th }} \text { Grade and then attended a regional high } \\
\text { school in the nearest town from Grade } 7 \text { through Grade } 12 \ldots . . " \text { (School) }\end{array}$ \\
\hline $\begin{array}{l}\text { Other } \\
\text { Love } \\
\text { Discovery } \\
\text { Wisdom } \\
\text { Tragedy } \\
\text { Passion } \\
\text { Friendship } \\
\text { Political } \\
\text { Philosophical } \\
\text { Spiritual } \\
\text { Exceptional }\end{array}$ & $\begin{array}{l}\text { "With time passing, the bond between us got tighter. It was as if all this time we were } \\
\text { building up a wall, brick by brick, to protect us from what was to come, as if we made a } \\
\text { mutual, silent promise to help and be there for each other forever." (Love) } \\
\text { "I hurried back home, got on the computer and found out that it was the holding building for } \\
\text { the Japanese going back to Japan in 1946. This was later confirmed by someone who was } \\
\text { working there at that time." (Discovery) } \\
\text { "The next morning, we took her to the doctor, and he told us she had MS. That is multiple } \\
\text { sclerosis." (Tragedy) }\end{array}$ \\
\hline
\end{tabular}

\section{Table 1b. Variables Coded in Addition to Story Type}

\begin{tabular}{|c|c|}
\hline Topics & Excerpts \\
\hline $\begin{array}{l}\text { Main characters } \\
\text { Personal } \\
\text { Family } \\
\text { Friend } \\
\text { Other people } \\
\text { Animal } \\
\text { Nature } \\
\text { Object }\end{array}$ & $\begin{array}{l}\text { "My first thought was to go back and tell them I couldn't do it, but I don't like to fail. I like to } \\
\text { achieve. I had to overcome my panic..." (Personal) } \\
\text { "I'd like to tell you the story about a cabin which plays an important role in the life of my } \\
\text { family." (Object) }\end{array}$ \\
\hline $\begin{array}{l}\text { Temporality } \\
\text { Single events } \\
\text { Series of events }\end{array}$ & $\begin{array}{l}\text { "One year, I was voted in as May Queen of Murrayville School. This was a big deal in those } \\
\text { days and I was thrilled. (Single event) }\end{array}$ \\
\hline $\begin{array}{l}\text { Phase of life } \\
\text { Childhood } \\
\text { Teenager } \\
\text { Adulthood } \\
\text { Later life }\end{array}$ & $\begin{array}{l}\text { "There was no water or electricity. Mom carried water from the neighbour's tap but she said } \\
\text { she was afraid to light the kerosene lamp..." (Childhood) }\end{array}$ \\
\hline $\begin{array}{l}\text { Location } \\
\text { Canada } \\
\text { Other countries }\end{array}$ & $\begin{array}{l}\text { "I went diving at Tobermory in Geogian Bay. Another fearful event happened on a wreck } \\
\text { dive with limited visibility." (Canada) }\end{array}$ \\
\hline $\begin{array}{l}\text { Affective tone } \\
\text { of the story } \\
\text { Sad } \\
\text { Happy } \\
\text { Neutral } \\
\text { Both }\end{array}$ & $\begin{array}{l}\text { "And although we were closely connected, we managed to hang on to our uniqueness, } \\
\text { become individuals of a distinctive style, and have strong personal views." (Happy) }\end{array}$ \\
\hline $\begin{array}{l}\text { Affective tone } \\
\text { of the ending } \\
\text { Sad } \\
\text { Happy } \\
\text { Neutral } \\
\text { Both }\end{array}$ & $\begin{array}{l}\text { "But I eventually found the deeper roots of my dad's trauma and the effect on him and our } \\
\text { family." (Neutral) }\end{array}$ \\
\hline
\end{tabular}


Story transcripts. Transcripts of the digital stories were coded to provide the data for this study. Most participants provided written transcripts of their digital stories, and a trained person

transcribed the remaining ones from the participants' videos.

Coding framework. The researchers developed a coding framework by reviewing the related literature and several transcripts. The Digital Storytelling Cookbook (Lambert, 2010) ${ }^{11}$ provided the foundational types of stories to be analyzed, and the researchers added several types to build a more robust framework (Table 1a) that covered the stories. To provide more depth, other story features (main characters, temporality, life phase, location, and affective tone of the story and the story ending) were also coded for each story (Table 1b).

Data coding. A content analysis approach (Mayring, 2004) ${ }^{12}$ was used to determine the types and features of our participants' stories. For coding, we used the categorical-content approach (Lieblich, Tuval-Mashiach, \& Zilber, 1998) ${ }^{13}$ by separating, classifying, and gathering utterances into defined categories based on Lambert's (2010) ${ }^{11}$ life story types (important person, life event, place, what someone does, recovery, love, or discovery) as well as the ones we added. (Table 1). We looked for referential clauses that revealed what each story was about (Labov \& Waletzky, 1997) ${ }^{14}$.

In qualitative research, data has to be analyzed iteratively to find patterns, which can provide an overall view of the whole phenomenon (Strauss \& Corbin, 1998) ${ }^{15}$. To do this, we first analyzed the stories' content to uncover the significant topics, coding each story using the classifying frame- work. Based on the topics that emerged from the stories, the framework was then modified: survival, political, and instructional categories were deleted, while military, family life, immigration, historical, travel, wisdom, tragedy, pass- ion, friendship, exceptional, philosophical, and spiritual categories were added. Thus, a combi- nation of open and closed coding was employed. The final step of axial coding consisted of comparing and defining the topics of the stories to find the connections and common topics among them.

Each story was described with primary and secondary type codes. A primary code reflected the most prominent type of story, i.e., the main focus of the story. As most stories included more than one type, we coded a secondary type for the less prominent focus of the story. For story statistics, the primary and secondary types were added to yield a total score for each story type.

Two faculty researchers, supported by a third, used this framework for several rounds of coding (Chu et al., 2016) ${ }^{16}$ during ten meetings, each of five hours duration, spread over a period of fifteen days. Selecting stories randomly, they coded $50 \%$ of the transcripts together, ensuring that full agreement was reached on all the variables that were coded. They then worked individually to code the remaining $50 \%$ of the stories, but in case of any confusion or uncertainty, they discussed the code assignments. Another researcher (the third author) conducted random spot checks of several scripts and verified the trustworthiness of the coding. The codes for each script were then added to the dataset containing each participant's demographic and background data.

\section{The Public Screening}

A public screening of 14 of these digital stories was held for two hours one evening. The stories were chosen to provide a great variety and this number was chosen to fit the two-hour time provided for the event. The audience was very diverse, ranging in age from teens to older adults, and comprising a mix of genders, and ethnic backgrounds. The audience consisted of the story creators, some of their families and friends, and members of the public who had seen our promotional material in the local newspaper and elsewhere. Almost 100 people attended and 60 completed the questionnaire that we provided. Respondents were asked to rate each story during the pause provided after each story. In the end, they were asked which three stories 
were their favourites and why they chose these. They were then asked what lessons they had received from the stories and which emotions, if any, they had experienced.

Data analysis. Statistical analysis was conducted using SPSS24. Frequencies and crosstabs were run on the data. For the viewing audience data, a simple qualitative method was used to analyze the results.

\section{Results}

Among the 100 older adult participants, 84 were females and 16 were males. Approximately $43 \%$ of the participants were aged 75 or older. Over half $(56.6 \%)$ were not married, and over $77 \%$ lived alone and in their own home rather than in an assisted living or a nursing home. Approximately $85 \%$ had education beyond high school, and $95 \%$ were retired.

Table 2 shows the results for the story types for females and males and the primary type, secondary type and total (combining primary and secondary types). Among the 23 types of stories, three story types were ranked highest, each with a combined total of greater than $20 \%$. 'Character' type was ranked first, being created by $41.7 \%$ of females and $31.3 \%$ of males. The category that ranked second was 'place' (created by $28.6 \%$ of females and $31.3 \%$ of males), followed by 'family life' (created by $22.6 \%$ of females and $18.8 \%$ of males). The next two categories were 'accomplishment' (17\%) and 'career/school' (16\%). One unexpected result emerged which was that $25 \%$ of males had "wisdom" as their secondary story type. Other surprising results were that only one person (out of 100) created a story type of spiritual, exceptional, friendship, or tragedy, and no one created a story with the type of survivor or political.

Table 2. Comparison of Female and Male Older Adults' Primary and Secondary Digital Story Types $^{\mathrm{a}}$

\begin{tabular}{|c|c|c|c|c|c|c|c|c|c|}
\hline \multirow[b]{2}{*}{ Types of Stories } & \multicolumn{3}{|c|}{ Female $(n=84)$} & \multicolumn{3}{|c|}{ Male $(n=16)$} & \multicolumn{3}{|c|}{ Combined $(n=100)$} \\
\hline & $\begin{array}{l}\text { Prim }^{b} \\
(\%)\end{array}$ & $\begin{array}{r}\mathrm{Sec}^{\mathrm{C}} \\
(\%)\end{array}$ & Total (\%) & $\begin{array}{l}\text { Primb }^{b} \\
(\%)\end{array}$ & $\begin{array}{l}\mathrm{Sec}^{\mathrm{C}} \\
(\%)\end{array}$ & $\begin{array}{l}\text { Total } \\
\text { (\%) }\end{array}$ & $\begin{array}{l}\text { Prim }^{b} \\
(\%)\end{array}$ & $\begin{array}{l}\mathrm{Sec}^{\mathrm{c}} \\
(\%)\end{array}$ & $\begin{array}{l}\text { Total } \\
(\%)\end{array}$ \\
\hline Character & 28.6 & 13.1 & 41.7 & 12.5 & 18.8 & 31.3 & 26.0 & 14.0 & 40.0 \\
\hline Place & 17.9 & 10.7 & 28.6 & 6.3 & 25.0 & 31.3 & 16.0 & 13.0 & 29.0 \\
\hline Family life & 9.5 & 13.1 & 22.6 & 0 & 18.8 & 18.8 & 8.0 & 14.0 & 22.0 \\
\hline Accomplishment & 2.4 & 14.3 & 16.7 & 18.8 & 0 & 18.8 & 5.0 & 12.0 & 17.0 \\
\hline Career/school & 13.1 & 3.6 & 16.7 & 12.5 & 0 & 12.5 & 13.0 & 3.0 & 16.0 \\
\hline Historical & 2.4 & 11.9 & 14.3 & 6.3 & 6.3 & 12.6 & 3.0 & 11.0 & 14.0 \\
\hline Love & 6.0 & 9.5 & 15.5 & 6.3 & 0 & 6.3 & 6.0 & 8.0 & 14.0 \\
\hline Immigration & 2.4 & 8.3 & 10.7 & 12.5 & 0 & 12.5 & 4.0 & 7.0 & 11.0 \\
\hline Adventure & 4.8 & 6.0 & 10.8 & 12.5 & 0 & 12.5 & 6.0 & 5.0 & 11.0 \\
\hline Wisdom & 0 & 3.6 & 3.6 & 12.5 & 25.0 & 37.5 & 2.0 & 7.0 & 9.0 \\
\hline Discovery & 2.4 & 6.0 & 3.0 & 0 & 6.3 & 6.3 & 2.0 & 6.0 & 8.0 \\
\hline Travel & 2.4 & 4.8 & 7.2 & 6.3 & 0 & 6.3 & 3.0 & 4.0 & 7.0 \\
\hline Passion & 2.4 & 4.8 & 7.2 & 0 & 6.3 & 6.3 & 2.0 & 5.0 & 7.0 \\
\hline Recovery & 6.0 & 1.2 & 7.2 & 0 & 0 & 0 & 5.0 & 1.0 & 6.0 \\
\hline Military & 0 & 4.8 & 4.8 & 0 & 6.3 & 6.3 & 0 & 5.0 & 5.0 \\
\hline Philosophical & 0 & 3.6 & 3.6 & 0 & 0 & 0 & 0 & 3.0 & 3.0 \\
\hline Spiritual & 0 & 0 & 0 & 6.3 & 0 & 6.3 & 1.0 & 0 & 1.0 \\
\hline Exceptional & 1.2 & 0 & 1.2 & 0 & 0 & 0 & 1.0 & 0 & 1.0 \\
\hline Friendship & 1.2 & 0 & 1.2 & 0 & 0 & 0 & 1.0 & 0 & 1.0 \\
\hline Tragedy & 0 & 1.2 & 1.2 & 0 & 0 & 0 & 1.0 & 0 & 1.0 \\
\hline Survivor & 0 & 0 & 0 & 0 & 0 & 0 & 0 & 0 & 0 \\
\hline Political & 0 & 0 & 0 & 0 & 0 & 0 & 0 & 0 & 0 \\
\hline
\end{tabular}

${ }^{\text {aT }}$ Totals add to more than $100 \%$ as many stories were of more than one type.

bPrimary story type; secondary story type 
Table 3 shows the features of participants' stories other than story type. Regarding the main character feature of the stories created by the participants, female and male choices were similar. Both prioritized personal characters (females $84.5 \%$, males $87.4 \%$ ) followed by family (females $67.9 \%$, males $50 \%$ ). However, one difference was that $25 \%$ of stories by male older adults were about friends compared to only $4.8 \%$ by female older adults. About half of both females and males wrote their stories about childhood, while about a third wrote about adulthood. More male older adults wrote stories about nature $(12.5 \%)$ compared to female older adults $(1.2 \%)$. The majority of participants created stories with multiple events $(87 \%)$ rather than single-event stories (13\%).

Finally, the affect of the stories was neutral for approximately half of the stories (46\%), as was the ending (47\%), while $46 \%$ of the stories had a happy ending.

Table 3. Comparison of Digital Story Features between Female and Male Older Adults

\begin{tabular}{|c|c|c|c|c|c|c|c|}
\hline & \multirow[t]{2}{*}{ Story Feature } & \multicolumn{2}{|c|}{ Female $(n=84)$} & \multicolumn{2}{|c|}{ Male $(n=16)$} & \multicolumn{2}{|c|}{ Combined $(n=100)$} \\
\hline & & $n$ & $\%$ & $n$ & $\%$ & $n$ & $\%$ \\
\hline \multirow[t]{4}{*}{ Main Character(s) } & Personal & 71 & 84.5 & 14 & 87.5 & 85 & 85 \\
\hline & Family & 57 & 67.9 & 8 & 50 & 65 & 65 \\
\hline & Friends & 4 & 4.8 & 4 & 25 & 8 & 8 \\
\hline & Other people & 1 & 1.2 & 1 & 6.3 & 7 & 7 \\
\hline \multirow[t]{3}{*}{ Main subject } & Animal & 4 & 4.8 & 1 & 6.3 & 5 & 5 \\
\hline & Nature & 1 & 1.2 & 2 & 12.5 & 3 & 3 \\
\hline & Object & 8 & 9.5 & 1 & 6.3 & 9 & 9 \\
\hline \multirow[t]{2}{*}{ No. of events in the story } & Single & 10 & 11.9 & 3 & 18.8 & 13 & 13 \\
\hline & Series & 74 & 88.1 & 13 & 81.3 & 87 & 87 \\
\hline \multirow[t]{4}{*}{ Starting time of the story } & Childhood & 41 & 48.8 & 9 & 53.6 & 50 & 50 \\
\hline & Teenage & 10 & 11.9 & 1 & 6.3 & 11 & 11 \\
\hline & Adulthood & 29 & 34.5 & 5 & 31.3 & 34 & 34 \\
\hline & Old age & 4 & 4.8 & 1 & 6.3 & 5 & 5 \\
\hline \multirow[t]{4}{*}{ Location of the story } & Canada primary & 7 & 8.3 & 0 & 0 & 7 & 7 \\
\hline & $\begin{array}{l}\text { Another country } \\
\text { primary }\end{array}$ & 12 & 14.3 & 1 & 6.3 & 13 & 13 \\
\hline & Canada secondary & 59 & 70.3 & 11 & 68.8 & 68 & 68 \\
\hline & $\begin{array}{l}\text { Another country } \\
\text { secondary }\end{array}$ & 24 & 28.6 & 5 & 31.3 & 28 & 28 \\
\hline \multirow[t]{4}{*}{ Affect of the story } & Neutral & 42 & 50 & 10 & 62.5 & 52 & 52 \\
\hline & Sad & 7 & 8.3 & 1 & 6.3 & 8 & 8 \\
\hline & Happy & 18 & 21.4 & 4 & 25 & 22 & 22 \\
\hline & Both & 16 & 19 & 10 & 63 & 17 & 17 \\
\hline \multirow[t]{4}{*}{ Affect of the ending } & Neutral & 39 & 46.4 & 7 & 43.8 & 46 & 46 \\
\hline & Sad & 4 & 4.8 & 0 & 0 & 4 & 4 \\
\hline & Happy & 38 & 45.2 & 9 & 56.3 & 47 & 47 \\
\hline & Both & 3 & 3.6 & & 0 & 3 & 3 \\
\hline
\end{tabular}

${ }^{a} \mathrm{~A}$ story could have more than one feature within this category.

The following is a summary of the results from the 60 respondents. More details will be presented in a later paper. When viewers were asked to provide the reasons for selecting their three chosen stories, some of the main reasons given for their choices were: 
- powerful message or meaning; because they had a powerful message or meaningful;

- reflection of determination and perseverance of the individual's family;

- valuable life-lessons;

- implicit inspiration to overcome adversity. Viewers were then asked what lessons if any, they received from watching the stories. Some of the responses provided were:

- accepting differences,

- being thankful,

- caring can come in surprising ways,

- cherishing people's kindness,

- giving gratitude,

- let people know you value them-while they are still alive.

Finally, the viewers were asked what emotions, if any, they experienced while viewing the stories. A wide range of emotions was reported, such as:

- crying,

- elation,

- empathy,

- joy,

- happiness,

- nostalgia.

\section{Discussion}

The findings suggest that 'character', 'place', and 'family' were the primary types of story that older adults choose to leave as their legacy digital stories. 'Accomplishment' and 'career/school' were the next most prominent story types. In this research, we found that the stories about a character or an individual were mostly personal or related to a family member. Writing about a family member can be more comfortable as the authors articulate their point of view as an outsider, and therefore, can discuss the facts the way they know them, without claiming complete truth as expected in first-person narration. This finding is in line with Solies's (2004) ${ }^{3}$ "family" type of legacy story.
'Place' was also found as a common type of legacy digital story, serving to anchor stories and not just as the "setting." As argued in stories about a character, the authors take an external focalization, which gives them the perspective of the whole story. The facts are presented as seen through a personal window, even though these facts are embedded with subjective inflection. The authors are empowered with the truth they remember about the story and about each of the characters that act in the place or event. Writing about a place or an event also favours the conscious presentation of space and sequentiality. Both are fundamental categories that structure human experience (Ryan, 2009) ${ }^{17}$. Ryan describes events as changes in states that affect an individual. Thus, recounting an event assists the process of thinking about the protagonists of that event, their interactions, and the consequences of these interactions. Furthermore, the place is described in the legacy digital story in the literal sense, a confined space where the events happened. The place is used as the setting or the narrative space of the story, and it is also impregnated with subjective inflection as if acting as a character. The place is described as a living being, with a spirit capable of influencing the cause-effect motion of the stories. This is consistent with Martin and Plum's (1997) ${ }^{18}$ genre of 'recount' that is about a sequence of events.

Family life follows as the third most explored story type for a legacy digital story, which corresponds to Berntsen and Rubin (2004) ${ }^{19}$ themes related to children and home-leaving events. According to Hunter $(2008)^{2}$, people tend to describe kindness among family members, their talents, and stories of them overcoming obstacles or growth. Moreover, writing about family life supports an outsider point of view. The recurrence of this window of focalization suggests that people tend to write about those situations of which they are not the main character and doing so, they are not put in a disclosure position. They reveal their legacy using a diegetic narrative, where the verb comes from multiple mouths and hearts. However, 
family life is not a primary theme for men as compared to women.

The story type of accomplishment is seen as a break from the authors' daily life routine or a challenge that people choose to undertake. Accomplishment can be understood as an important life event that helped increase the storyteller's self-esteem, and thus people like to tell what they had to do to overcome the challenges the faced.

Another preferred type of legacy digital story is career/school. This topic is used to address an important turning point in someone's life. These stories' themes endorse Berntsen and Rubin's $(2004)^{19}$ statement that people tend to activate the life script when they are asked to tell a positive event about their lives. They also tend to recount positive events early in adult life, which is the corresponding time for stories about a career. In the Berntsen and Rubin (2004) ${ }^{19}$ study, people preferred to tell a story about beginning school and college and getting a job.

One of the features that we noticed in these stories is that our participants tended to write about themselves and family members. In many of the character stories, the authors describe themselves in secondary roles. The story is shaped from their point of view and their memories of the facts. That is why we argue that the window of focalization is character-based. In addition, people write about their families because family members are the characters that have greatly influenced the authors' beliefs, culture, and what they have become. Another important finding is that the stories are organized in a series of events because a legacy is more likely to be formed after several cause-effect episodes. Legacy comes from recalling memories, which gravitate around a long period.

We also found that older adults wrote more about their childhood. These findings are consistent with other studies that point out that people over 40 years of age have significantly more memories of adolescence and young adulthood than later life periods. This reminiscence bump (Koppel \& Berntsen, 2015) ${ }^{20}$ is not entirely verified in our study because our older adults remembered (or told) more about childhood than teenage years. This result might be because we worked with older people and the majority were women. In this case, women wrote more about character and family life, which motivated stories about childhood. Approaching stories about their childhood and adult life resulted in the place of most stories being in Canada.

The emotional tone is neutral or happy because people may try to find a reason for the sad things that happened to them. These reasons impose a more neutral tone to the stories. These findings confirm the predominance in counting positive events as argued by Berntsen and Rubin $(2004)^{19}$. However, females wrote a greater number of sad stories $(8.3 \%)$ and stories with a sad ending (4.8\%) as compared to the males (6.3\% and 0 respectively). This is in line with the findings of Alea, Bluck, and Semegon (2004) ${ }^{21}$.

Therefore, based on our study, we found that the various types of stories, which the older adults chose to leave as their legacy were: character, place, family life, accomplishment, and career /school. It seems that the older adults saw these themes as the most important ones to share with younger generations. These themes could be interpreted as organic legacy (Solie, 2004) ${ }^{3}$ because they are a result of a process, whereby the older adults had to review their lives from a higher perspective to figure out what they value the most. The memories that form these stories were organized in order to establish a sense that the authors had lived a productive life, and all of the written memories led to wisdom and satisfaction of passing a learning experience to the next generations.

The majority of the photographs used to illustrate the stories were digitalized from authors' family albums. The aesthetics of these photo- graphs (black and white, composition, etc.) imprinted a high degree of indexicality, that is, the viewer believes the photographs reflect reality (Barthes, 1981) ${ }^{22}$. Therefore, the photographs are a 
means to transport the viewer to the authors' story world (Bazin, 1967) 23 .

In addition, the narration gives another layer of truth and empathy. Like photographs, narration supports indexicality because of all the indexical information that the speech provides (Dellwo, Pellegrino, He, \& Kathiresan, 2019) ${ }^{24}$. This information can be emotion and sincerity, the tone of the voice, pace, utterance, and the structure of each sentence.

Finally, the results of the small study of viewers' reactions to the digital stories provide support for older adults to use digital stories as both a source of life wisdom and a legacy for younger generations.

A digital story is a powerful artifact to communicate an older person's legacy because it is based on familiar forms of communication, such as speech and photographs. This familiarity acts as a natural composer as these media are used to support the story being told. The product is the digital story; the meaning is the legacy.

Likewise, the narrative is the structure that creates a bridge between the creator and the viewer. The form of a story supports making sense of legacy. The preferred choice of a character or a place theme also indicates that we remember in a narrative structure as argued by Polkinghorne (1988) 25 .

Our next step will be to examine the associations between the different types and features of stories and the demographic characteristics of storytellers. We wish to determine whether story types are different based on gender, age, social living conditions, and other demographic factors. We would also do a more in-depth and rigorous study of viewers' reactions to viewing the digital stories. For example, do the stories have any impact on family members?

\section{References}

1. Robinson, J. T., \& Murphy-Nugen, A. B. (2018). It makes you keep trying: Life review writing for older adults. Journal of Gerontological Social Work, 61(2), 171-192. doi:10.1080/01634372.2018.1427645
2. Hunter, E. G. (2007-2008). Beyond death: Inheriting the past and giving to the future, transmitting the legacy of one's self. OMEGA Journal of Death and Dying, 56(4), 313-329. https://doi.org/10.2190/OM.56.4.a

3. Solie, D. (2004). How to say it to seniors Clossing the communication gap with our elders. New York, NY: Prentice-Hall.

4. Pevny, R. (2016, May 13). Creating the legacy of your elderhood. Retrieved from https://www.centerforconsciouseldering.com/wpcontent/uploads/2017/04/legacy.pdf

5. Hunter, E. G., \& Rowles, G. D. (2005). Leaving a legacy: Toward a typology. Journal of Aging Studies, 19(3), 327-347. doi:10.1016/j.jaging.2004.08.002

6. Scott, K., \& Debrew, J. K. (2009). Helping older adults find meaning and purpose through storytelling. Journal of Gerontological Nursing, 35(12), 38-43. doi:10.3928/00989134-2009110303

7. Jenkins, T., 2015. Digital words of wisdom? Digital storytelling with older people - Ponderings of a (fairly) new $\mathrm{PhD}$ research candidate and a (growing) older digital storytelling practitioner. Cultural Science Journal, 8(2), 43-62. doi:10.5334/csci.81

8. Pecorini, B. C., \& Duplàa, E. (2017). Narrative gerontology and digital storytelling: What benefits for elders? MOJ Public Health 6(6), 00192. doi:10.15406/mojph.2017.06.00192

9. Hewson, J., Danbrook, C., \& Sieppert, J. (2015). Engaging post-secondary students and older adults in an intergenerational digital storytelling course. Contemporary Issues In Education Research, 8(3), 135-142. Doi:10.19030/cier.v8i3. 9345

10. Hausknecht, S., Vanchu-Orosco, M., \& Kauf- man D. (2017). Sharing life stories: Design and evaluation of a digital storytelling workshop for older adults. In G. Costagliola, J. Uhomoibhi, S. Zvacek, \& B. McLaren (Eds.), Computers Supported Education. CSEDU 2016. Communications in Computer and Information Science ( $v$. 739, pp. 497-512). Cham, Switzerland, Sprin- ger. doi:10.1007/978-3-319-63184-4_26

11. Lambert, J. (2010). Digital storytelling cookbook. Berkley, CA: Digital Diner Press. Retrieved from https://wrd.as.uky.edu/sites/default/files/cookboo k.pdf

12. Mayring, P. (2004). Qualitative Content Analy- sis. In U. Flick, E. v. Kardoff, \& I. Steinke, A Companion to Qualitative Research (pp. 266-275). London: Sage.

13. Lieblich, A., Tuval-Mashiach, R., \& Zilber, T. (1998). Narrative research: Reading, analysis, 
and interpretation. Thousand Oaks, CA: SAGE Publications.

14. Labov, W., \& Waletzky, J. (1997). Narrative analysis: Oral versions of personal experience. Journal of Narrative \& Life History, 7(1-4), 3-38. doi:10.1075/jnlh.7.02nar

15. Strauss, A. L. and Corbin, J. (1998) Basics of qualitative research: Grounded theory procedures and techniques (2nd ed.). London, UK: Sage Publications.

16. Chu, S., Garcia, B., Quance, T., Geraci, L., Woltering, S., \& Quek, F. (2016). Understanding storytelling as a design framework for cognitive support technologies for older adults. In ITAP' 16: Proceedings of the International Symposi- um on Interactive Technology and Ageing Populations (pp. 24-33). New York, NY: ACM. doi:10.1145/2996267.2996270

17. Ryan, M. L. (2009, January 13). Space. In P. Hühn, J. Pier, W. Schmid, \& J. Schönert (Eds.), The living handbook of narratology. Hamburg, Germany: Hamburg University. Retrieved from http://www.lhn.uni-hamburg.de/article/space

18. Martin, J. R., \& Plum, G. A. (1997). Construing experience: Some story genres. Journal of Narrative and Life History, 7(1-4), 299-308. doi:10.1075/jnlh.7.37con

19. Berntsen, D., \& Rubin, D. C. (2004). Cultural life scripts structure recall from autobiographical memory. Memory \& Cognition, 32(3), 427-442. doi:10.3758/BF03195836

20. Koppel, J., \& Berntsen, D. (2015). The peaks of life: The differential temporal locations of the reminiscence bump across disparate cueing methods. Journal of Applied Research in Memory and Cognition, 41(1), 66-80. Doi:10. 1016/j.jarmac.2014.11.004

21. Alea, N., Bluck, S., \& Semegon, A. B. (2004). Young and older adults' expression of emoti-onal experience: Do autobiographical narrati- ves tell a different story? Journal of Adult Development, 11(4), 235-250. Doi:10.1.023/B: JADE.0000044527.52470.5d

22. Barthes, R. (1981). Camera lucida: Reflections on photography. New York, NY: Hill and Wang.

23. Bazin, A. (1967). The ontology of the photographic image. Film Quarterly, 13(4), 4-9. doi: $10.2307 / 1210183$

24. Dellwo, V., Pellegrino, E., He, L., \& Kathiresan, T. (2019). The dynamics of indexical informa- tion in speech: Can recognizability be controlled by the speaker? AUC PHILOLOGICA, 2019, 57-75. doi:10.14712/24646830.2019.18

25. Polkinghorne, D. E. (1988). Narrative knowing and the human sciences. Albany, NY: State University of New York Press.
26. Abbott, H. P. (2002). The Cambridge introduction to narrative. Cambridge, UK: Cambridge University Press.

27. Bohn, A. (2010). Generational differences in cultural life scripts and life story memories of younger and older adults. Applied Cognitive Psychology, 24(9), 1324-1345. Doi:10.1002/ acp. 1641

28. Chatman, S. (1978). Story and discourse. Narrative structure in fiction and film. Ithaca, NY: Cornell University Press.

29. Hausknecht, S., Vanchu-Orosco, M., \& Kaufman, D. (2019). Digitising the wisdom of our elders: Connectedness through digital storytelling. Ageing \& Society, 39(12), 2714-2734. Doi:10.1 $0.1017 /$ S0144686X18000739

30. Schank, R. C. (1995). Tell me a story: Narrative and Intelligence (Rethinking theory). Evanston, IL: Northwestern University Press. 